\title{
Implementation of Automatic Plant Sprinkler Control System in RT 07 RW 08 Pabuaran Mekar Subdistrict, Cibinong, Bogor
}

\author{
Reza Diharja ${ }^{a}$, Wike Handini, Sri Wiji Lestari, Nur Witdi Yanto, and Renggo Mike Al'Aziz \\ Prodi Teknik Elektro, Fakultas Teknologi Industri, Universitas Jayabaya, DKI Jakarta, Indonesia \\ a)Corresponding author: reza.diharja@jayabaya.ac.id
}

\begin{abstract}
The COVID-19 pandemic is forcing humans to adapt and be more creative. The Women Farmers Forum (KWT) group in Pabuaran Mekar receives assistance for the success of the food security program in the form of P2L (Sustainable Food Courts). The purpose of the program is to ensure that the community receives quality food from its own environment to maintain and improve the nutrition of the surrounding community. The problems faced in KWT are watering plants that still rely on humans, which is carried out in the morning and afternoon. The manufacture of an automatic plant sprinkler control system reduces the role of humans because it is equipped with a timer program. Users need to know about how to use the system to make it more durable and it is given from a presentation that is aimed as training. The survey at the end of the presentation provided feedback that the activities carried out were very good with a score of $65 \%$ of respondents in terms of more than the presentation material, and $79 \%$ of respondents rated it very much in accordance with their benefits and expectations. More than $87.5 \%$ of the respondents scored an excellent overall quality of the activities.
\end{abstract}

Keywords: Automatic plant sprinkler control system, pabuaran mekar, KWT, P2L

\section{INTRODUCTION}

The Women Farmers Forum (KWT) "Melati" group located in the Pabuaran Asri, Pabuaran Mekar Subdistrict, Cibinong District, Bogor Regency, West Java Province, is one of the recipients of the Regional Incentive Fund (DID) assistance from local government. With these funds, KWT performs the Sustainable Food House Area Development Activity (Pengembangan Kawasan Rumah Pangan Lestari) with the aim of increasing family food security during the COVID-19 pandemic (Megi, 2020). The assistance provided was in the form of shelves as a place for plants and dozens of polybags as a nursery for vegetable seeds and a place to grow them. With this assistance, residents are expected to grow vegetables in their yards to meet the food needs of their families. According to the Minister of Agriculture of the Republic of Indonesia, the front land around the backyard of the house has the potential to be planted with fruits, vegetables and livestock. In addition, universities as centres of knowledge have technology and innovations that can be applied in the community to increase the food supply (Bogor Kita, 2020).

The partner for community service activities (P2M) is KWT RT 07 RW 08, which is part of the KWT "Melati" Pabuaran Asri, Pabuaran Mekar Subdistrict. Before carrying out the core program, the team first surveyed members of KWT RT 07 RW 08. Based on the diagram in Figure 1, 14 total respondents have completed the survey and the results can be concluded that a total of 5 respondents or $35.7 \%$ of the total respondents have an average monthly income less than IDR $1,000,000$ (Rahmasari, 2021). Based on these data, efforts that have a significant impact are needed, especially in increasing the economic level of KWT RT 07 RW 08 members. In addition, to make the benefits that have been provided by the local government feel longer, the vegetable plants that have grown need to be properly cared for and maintained. Plant care and maintenance includes fertilization, watering, and preventing pest attacks, all of which are done to obtain optimal yields, of course, with good plant quality. 


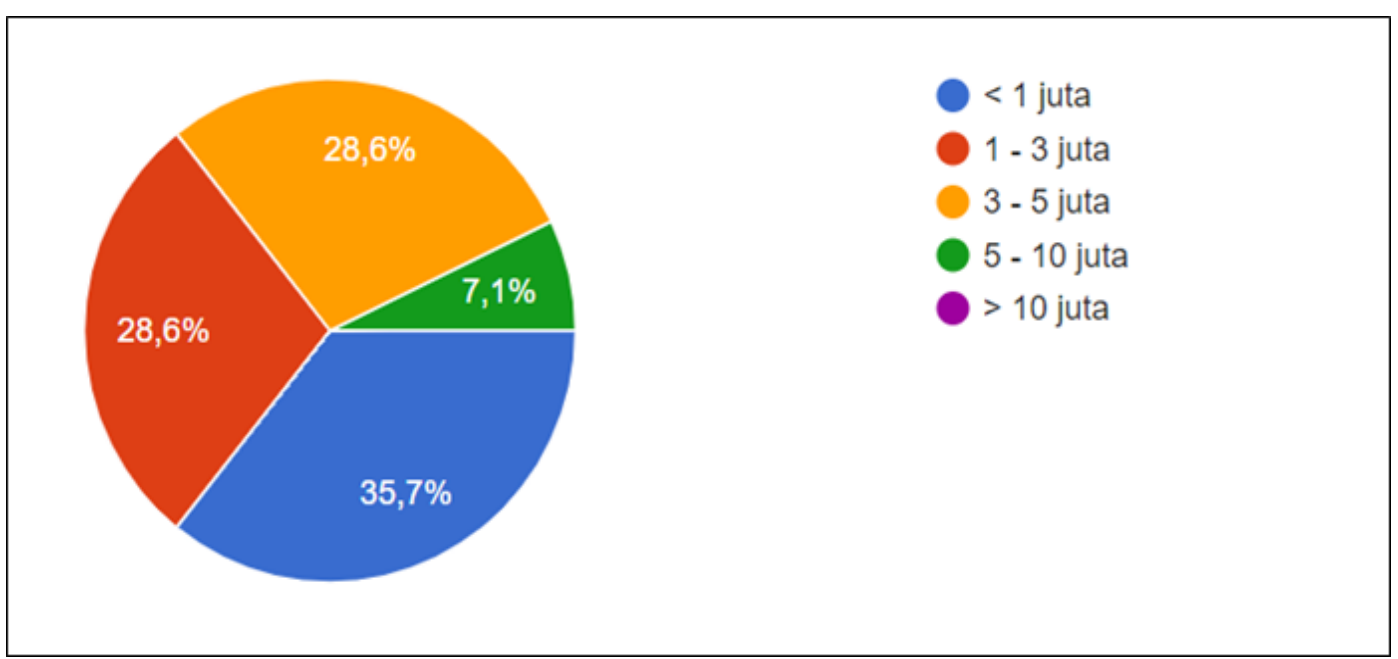

Figure 1. Average monthly income of P2M partner members

The meeting in the form of discussions conducted with partners KWT RT 07 RW 08 Pabuaran Mekar Sub-district, Cibinong, Bogor aims to find solutions to existing problems. One of the activities carried out by the KWT is planting vegetables such as pakchoi, lettuce and mustard greens. These plants must be cared for properly, such as providing adequate nutrition and watering in the morning and evening with adequate amounts of water. The current watering activity is still done manually and relies heavily on human labour, so innovation in the form of a tool is needed so that the watering process no longer relies entirely on human involvement.

Various kinds of reference models of automatic plant watering systems have been made and created by people and are even connected to the internet. For example, a tool made using a propeller and moisture sensor with the aim of being able to detect the level of soil moisture so that watering can be adjusted to the current soil moisture level (Ratnawati \& Silma, 2017). There is also an automatic plant watering system that can even be controlled via a device and soil moisture data is presented in real-time (Jatmiko, Ciptadi, \& Hardyanto, 2021). However, on this occasion, the design must prioritize ease of operation in terms of the sophistication of the tool because the majority of its users are people who are not experts in electronic device technology. Therefore, the design of the tool system to be built must be simple and, with a little bit of effort, the tool can already be operated.

\section{METHOD}

The main goal of this community service is to make an automatic plant sprinkler control system that will be applied to vegetable crops. Figure 2 is a schematic design of an electronic circuit as a solution to the problems that exist in KWT RT 07 RW 08 Pabuaran Mekar Cibinong. The central part of the system is a digital timer and an electric solenoid valve; these two components regulate the flow of water from the collection/water tank to the outside/pump booster.

\section{Table 1. Solutions offered in Community Service Activities}

\begin{tabular}{|c|c|c|c|}
\hline No. & Solutions & Descriptions & Output \\
\hline 1. & $\begin{array}{l}\text { In the form of counseling the } \\
\text { use of automatic plant } \\
\text { sprinkler control system } \\
\text { tools and their maintenance }\end{array}$ & $\begin{array}{l}\text { In the form of presentations } \\
\text { and training which are carried } \\
\text { out directly during the } \\
\text { installation of tools around } \\
\text { plants }\end{array}$ & $\begin{array}{l}\text { Community members } \\
\text { understand the } \\
\text { procedures for using and } \\
\text { maintaining these tools }\end{array}$ \\
\hline 2. & $\begin{array}{l}\text { In the form of distribution of } \\
\text { automatic plant sprinkler } \\
\text { control system tools } \\
\text { according to needs }\end{array}$ & $\begin{array}{l}\text { Installing tools around plants } \\
\text { and handing them over to } \\
\text { representatives of KWT RT } 07 \\
\text { RW } 08\end{array}$ & $\begin{array}{lr}\text { Set up automatic plant } \\
\text { sprinkler control system } \\
\text { tools and r photo } \\
\text { documentation } \\
\text { installed tools }\end{array}$ \\
\hline
\end{tabular}




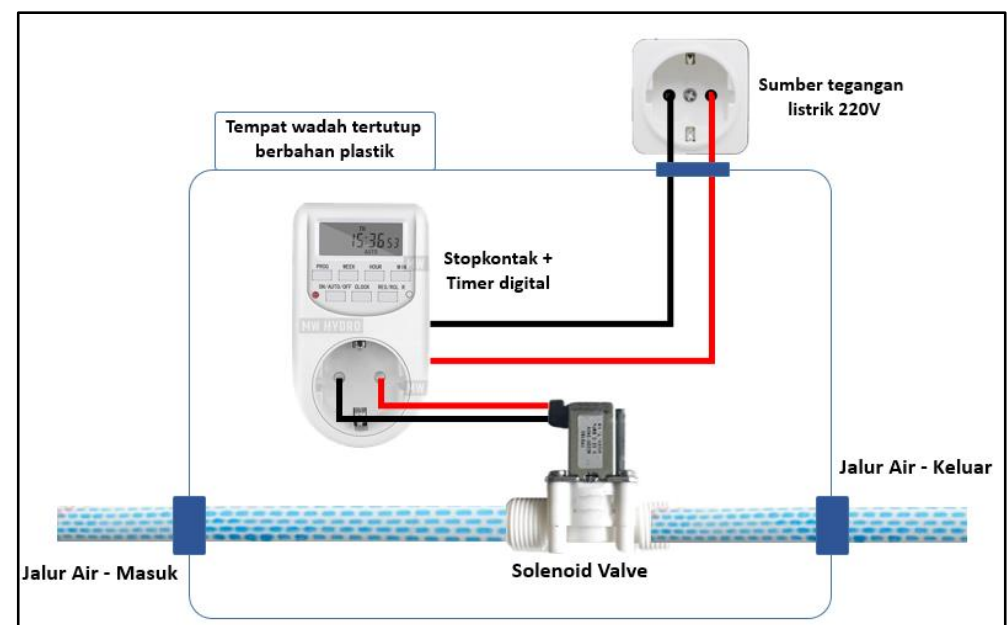

Figure 2. The main schematic of the automatic plant sprinkler control system

The implementation of community service activities which carried out has stages as shown in table 2.

Table 2. Activity stages and its descriptions

No. Activity Stages

1.

Outreach and interviews with activity partners

The design and manufacture of an automatic plant sprinkler control

2. system is carried out in the Control and Automation lab, Electrical Engineering, FTI-UJ

Provide counselling and training in the

3. form of procedures for the use and safety of automatic plant sprinkler control system tools to user partners

4. Donating 1 unit of the equipment

5.

Evaluation of equipment system and activities

\section{Activity Descriptions}

Direct visit to partner, KWT Melati RT 07

RW 08 Pabuaran Mekar, Cibinong, to obtain

information related to the problems experienced

The design and manufacture of the equipment are carried out by an electrical engineering lecturer and assisted by students

Conducted directly to partners and through visits and webinars

The automatic plant sprinkler control system tool that has been made is then adjusted to the needs of partners in the field Evaluate the reliability and durability of the tool. In addition, evaluation of all activities including virtual meetings

Research and testing at the FTI-UJ Electrical Engineering Automation and Control Laboratory kicked off community service activities in April 2021. As indicated in Figure 3, the purpose is to design and manufacture the best automatic plant sprinkler control system possible. Then, on Friday, June 4, 2021, continue with training and counseling on how to utilize the automatic plant sprinkler control system, which will be held both in person and electronically. Table 2 shows the event schedule, whereas the URL, meeting ID, and password for virtual meetings are as follows: Join Zoom Meeting: https://us02web.zoom.us/j/89683922626?pwd=NTUzTXF6WVFITFUzU2FFb3JrMG9OUT09

Meeting ID: 89683922626

Passcode: 03062021 


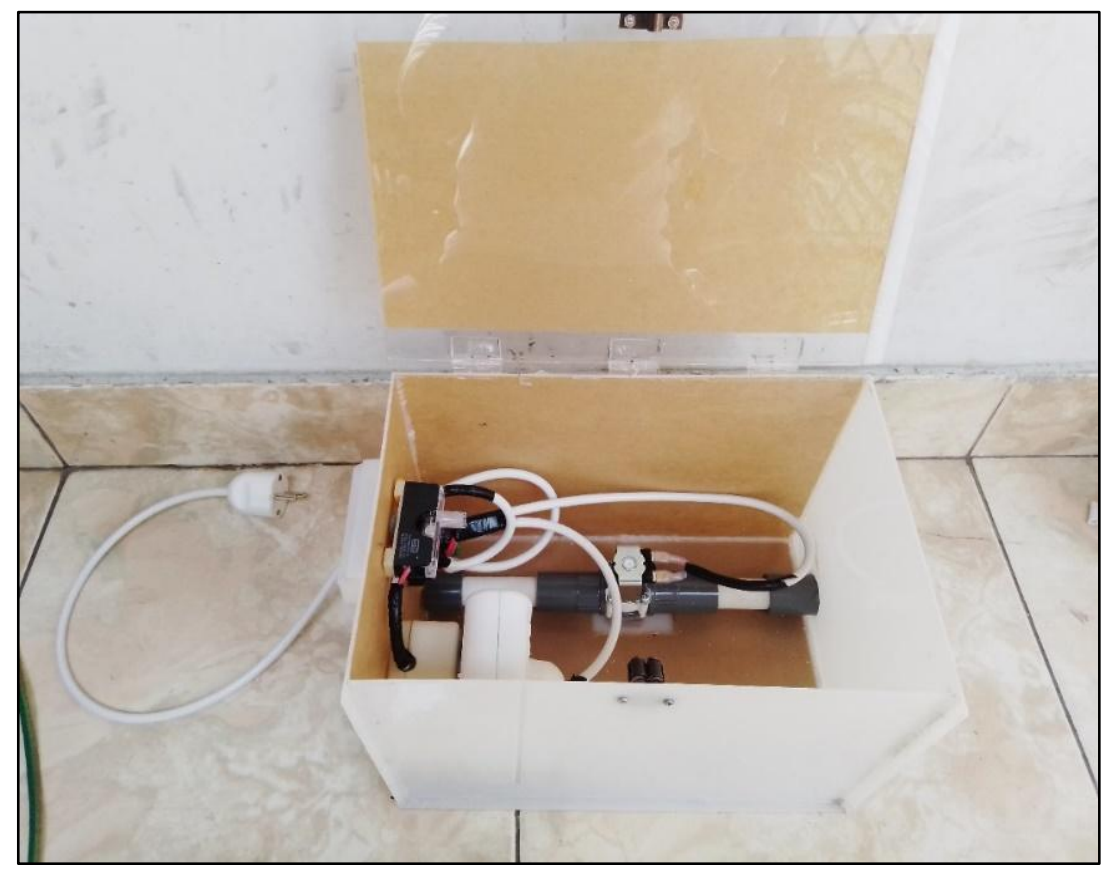

Figure 3. Automatic plant sprinkler control system

At the end of the training and direct counseling activities, participants who attended offline conducted a survey. The questions are loaded in Google form so that the data obtained is faster and more accurate. In addition, the main purpose of filling out this survey is to get feedback from the participants regarding the whole series of events as shown in Figure 4.

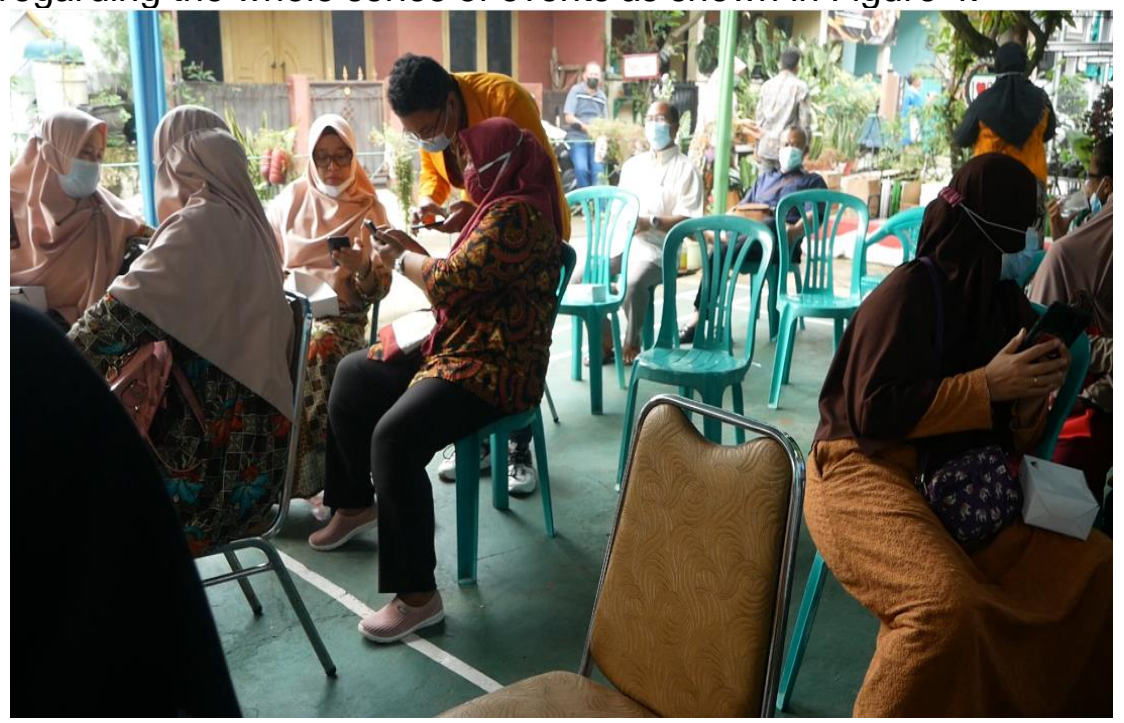

Figure 4. Respondents filling out surveys with the assistance of students

\section{RESULT}

The built-in automatic plant sprinkler system is then put around water sources and vegetable plants. The installed technology can then be utilized to help regulate the timing of watering plants. Furthermore, community service activities include training in the use and safety of equipment. These actions are carried out through presentations and counseling, as illustrated in Appendices 1 and 2.

Not only were invited guests, local regional leaders, (PLT) Cibinong District Head, and Pabuaran Mekar Subdistrict Head, present at the offline event. Following the completion of the presentation and counseling, the survey was distributed to invited guests or participants who attended offline, and the filling process was accompanied by students. After completion of the survey of all participants, there were 24 respondents who contributed to providing answers, and 
the results revealed that more than 65 percent of the participants gave a very good response from the entire series of community service activities.

\section{DISCUSSION}

The community service program at KWT RT 07 RW 08 Pabuaran Asri was carried out in collaboration with teams from other study programs other than electrical engineering, but with different goals and debates. Of the 24 participants or responders, 16 offered very high ratings for the material's clarity, 15 got very good ratings for understanding the information, and 16 gave very good ratings for the interactive and communicative components. Overall, the results are satisfactory because more than 65 percent of the respondents awarded each aspect a very good grade, as indicated in figure 7.

A total of 19 respondents gave a very positive rating of the activity's usefulness and the fit of their expectations for this activity. While the remainder provided suitable ratings, as indicated in the graph in figure 8, As indicated in the graph in figure 9, a total of 21 respondents awarded the facilitator's response (Tim PkM FTI Jayabaya) a very good score in terms of assisting participants and offering services or information, while 3 other respondents provided a good score. The quality of community service was judged very good by 21 respondents, or 87.5 percent, with the rest scoring it good, as indicated in the graph in figure 10.

\section{CONCLUSION AND RECOMMENDATION}

This community activity consisted of two parts: first, the creation of an automatic plant sprinkler control system equipment, and second, counseling/training in the form of presentations. As part of a full system, the equipment is then installed around water sources and vegetable fields. After presentation, data was collected through the survey, which was completed by 24 respondents. The data shows that this effort has been quite successful overall. This is a long-term program and it is hoped that in the future, KWT RT 07 RW 08 Pabuaran Asri would be self-sufficient in terms of resources and food for the community.

\section{ACKNOWLEDGEMENTS}

The authors thank FTI-UJ who has financed community service activities in the Pabuaran Mekar Subdistrict, Cibinong District, Bogor.

\section{REFERENCES}

Bogor Kita. (2020, Agustus 6). Kementan Gandeng IPB dalam Pendampingan Pekarangan Pangan Lestari. Dipetik April 2021, dari https://bogor-kita.com/kementan-gandeng-ipbdalam-pendampingan-pekarangan-pangan-lestari/

Jatmiko, W., Ciptadi, P. W., \& Hardyanto, R. (2021). Sistem Penyiram Tanaman Otomatis Berbasis Mikrokontroler dan Panel Surya. SEMINAR NASIONAL Dinamika Informatika 2021 (hal. 199-203). Yogyakarta: Universitas PGRI .

Megi, R. (2020, Desember 29). DKP Pemkab Bogor Dan KWT Melati, Panen Perdana Di Lahan Fasum. Dipetik April 2021, dari http://bogoronline.com/2020/12/dkp-pemkab-bogor-dankwt-melati-panen-perdana-di-lahan-fasum/

Rahmasari, F. (2021). Analisis Hasil Survey Kebutuhan Mitra. Jakarta: FTI-UJ.

Ratnawati, \& Silma. (2017). Sistem Kendali Penyiram Tanaman Menggunakan Propeller Berbasis Internet of Things. Jurnal Inspiration, 143-154. 


\section{APPENDIX}

Untuk Peningkatan Rualitas Sayuran Organik Yan gan di RT 07 RW 08, Relurahan Pabuaran Mekar.

in Cibinong, Kabupaten Bogor, Jawa Barat"

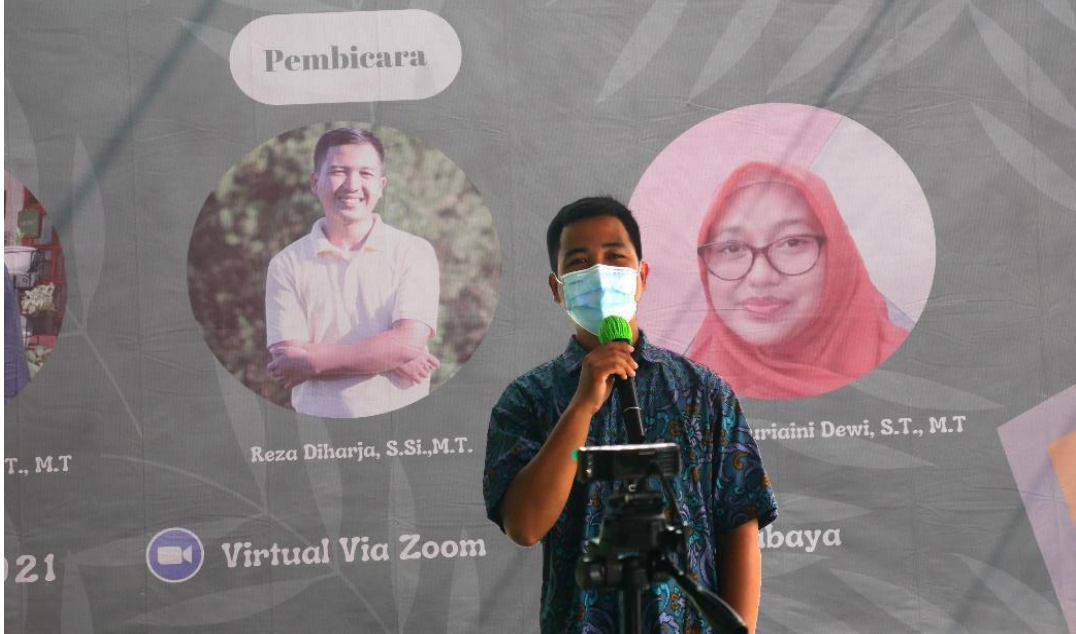

Figure 5. Presenting the materials about using the sprinkler system and its safety in the community service program in Pabuaran Asri, Cibinong

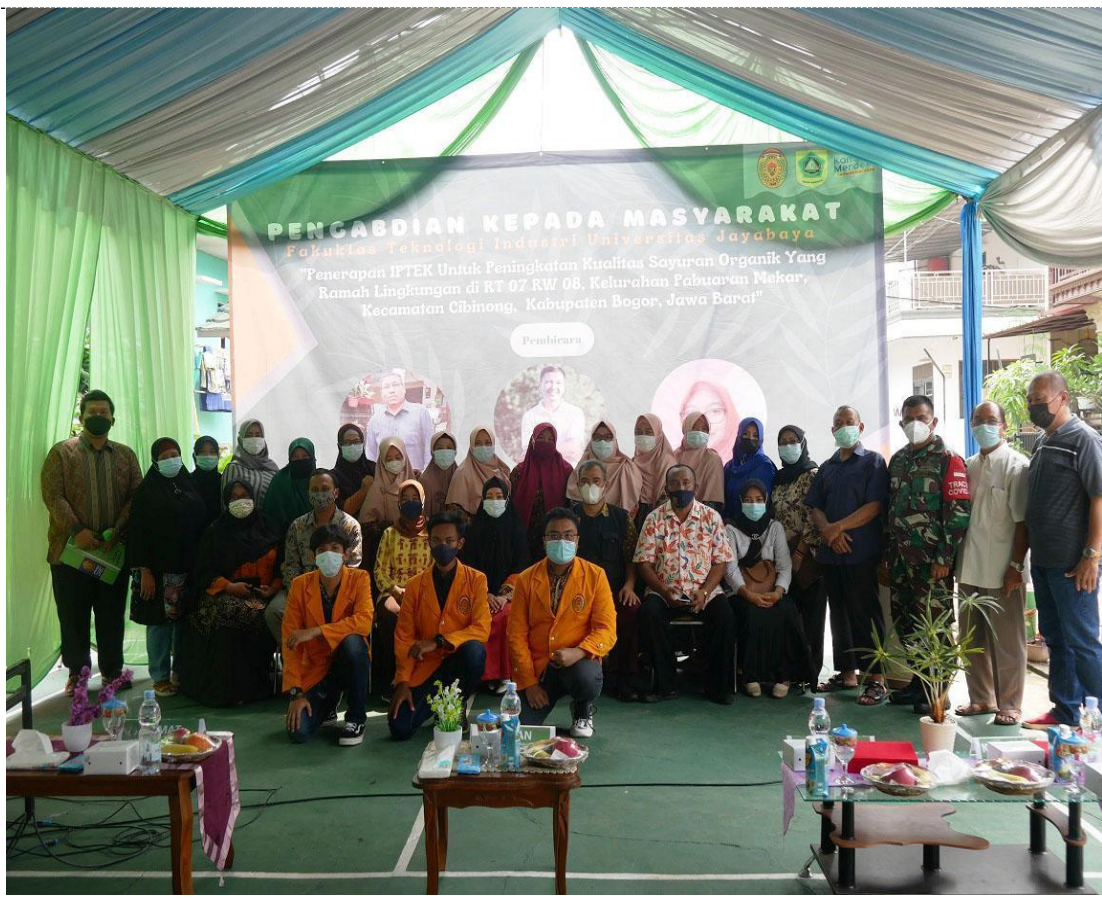

Figure 6. Photo session after the whole program is ended 


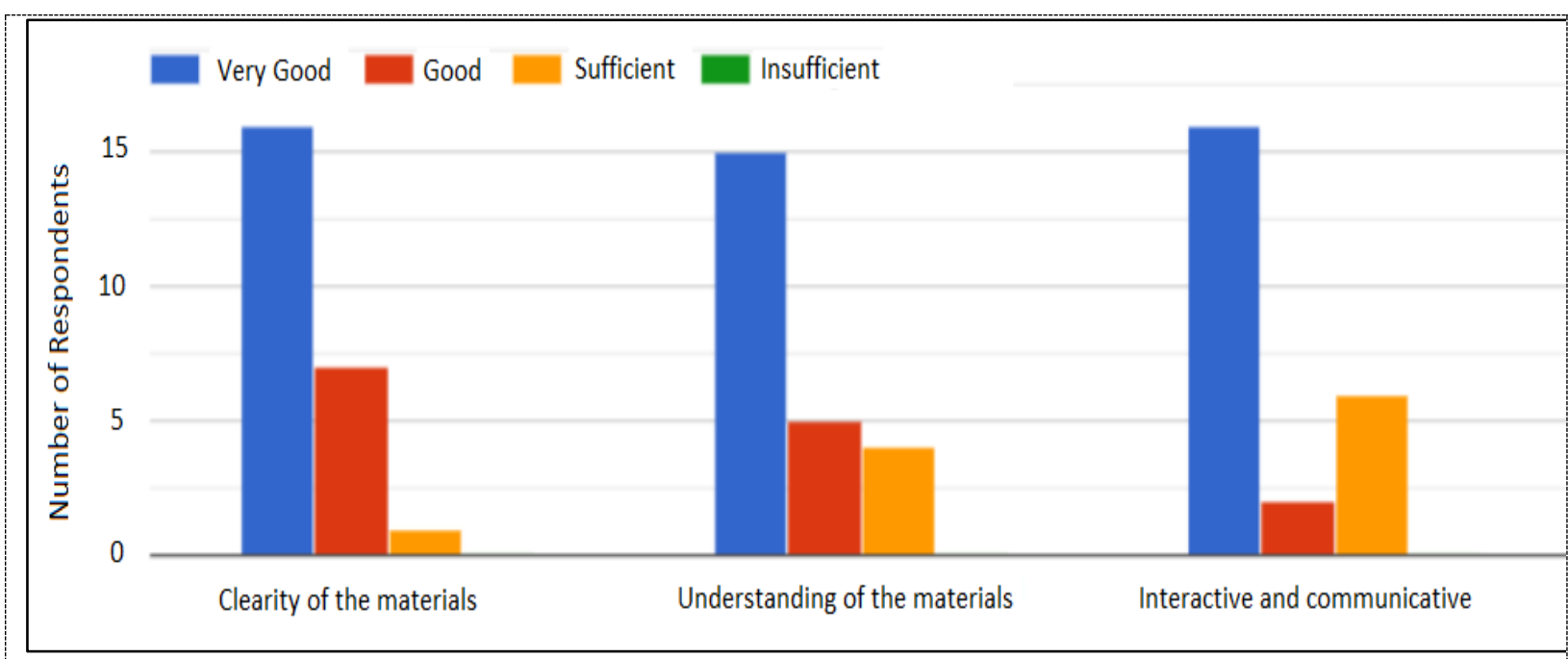

Figure 7. The assessment about $2^{\text {nd }}$ presentation materials by the respondents

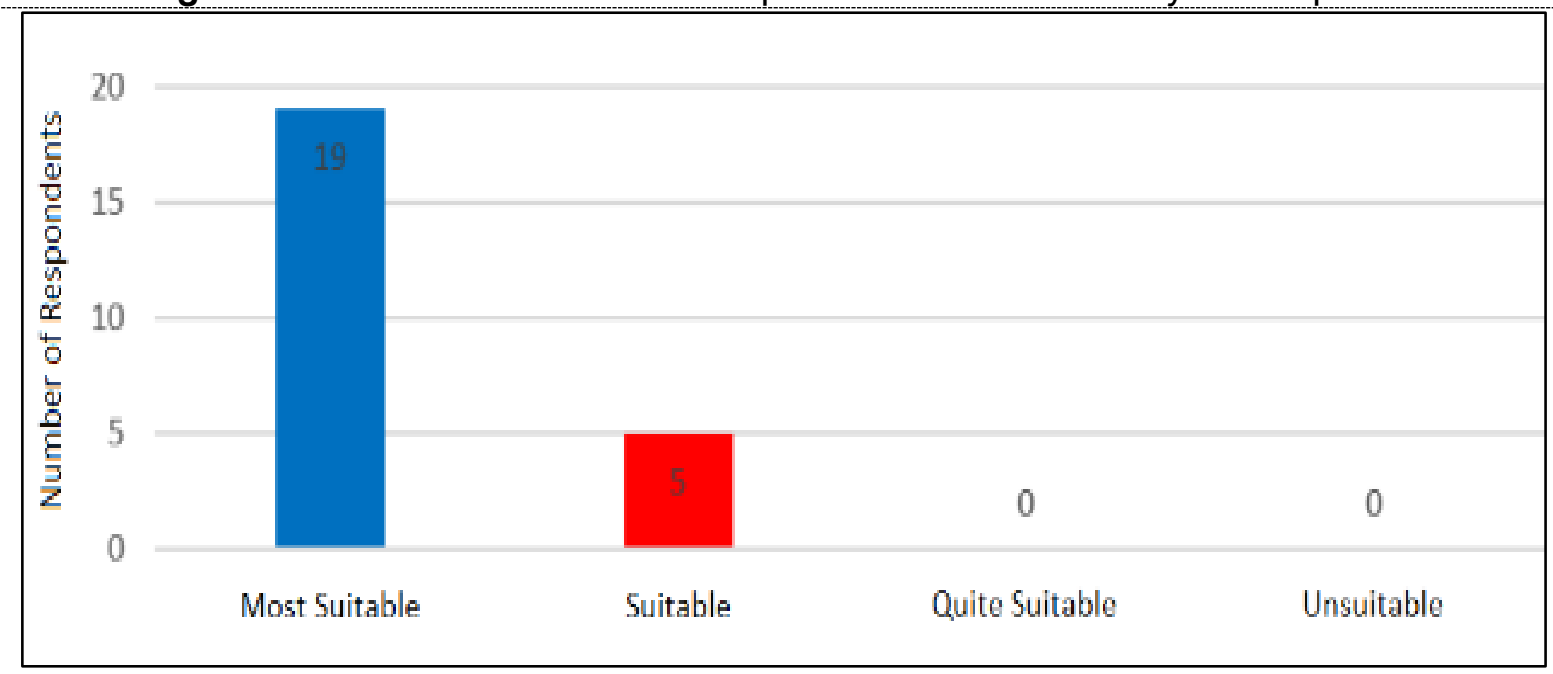

Figure 8. The assessment of usefulness of community service program

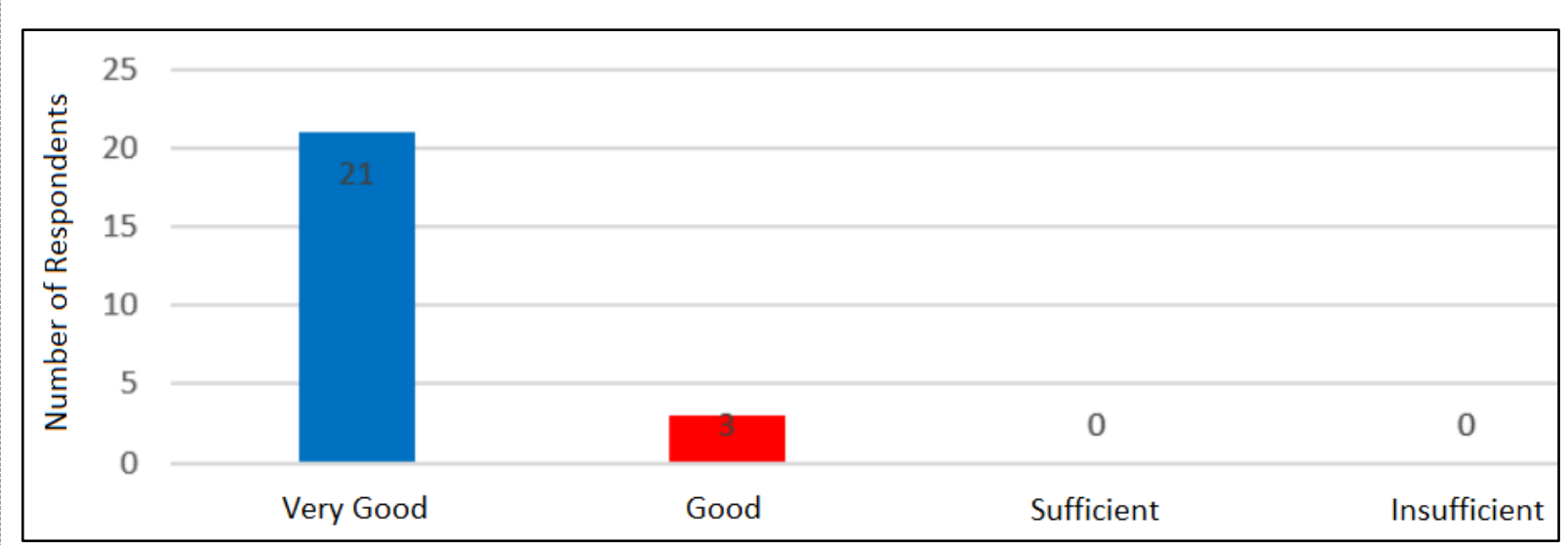

Figure 9. The assessment of the facilitator of community service in helping the respondents 


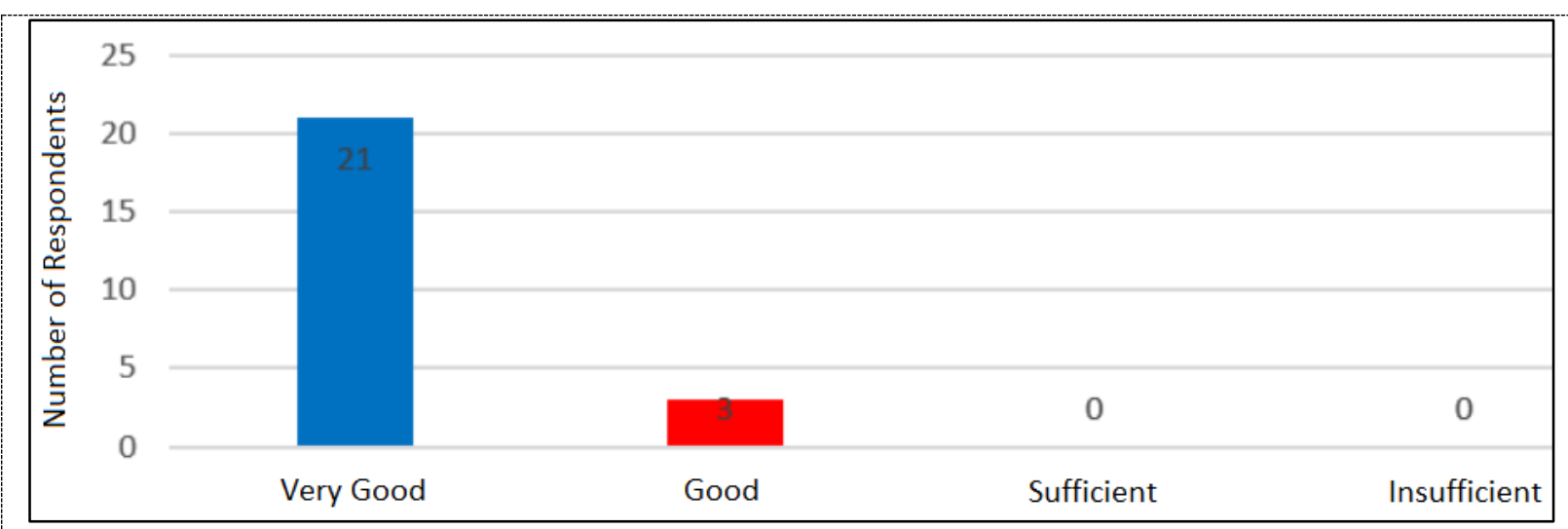

Figure 10. The assessment of the overall of community service program 